to the surgeons at the Royal National Orthopaedic Hospital, to Mr. D. Brooks (Barnet), Mr. M. Pilcher (Hackney), Mr. P. H. Newman (Middlesex Hospital), Mr. E. L. Trickey (Edgware), Mr. K. I. Nissen (Watford), and Mr. G. C. Lloyd-Roberts (Hospital for Sick Children) for allowing me to examine their patients. It is a pleasure to record my appreciation of the help I have received from the staff of the Medical Records Department of the Royal National Orthopaedic Hospital, and from Dr. C. H. Lack and his staff in the Pathology Department of the Institute of Orthopaedics, Stanmore. Mr. R. Whitley and his assistants in the Medical Photographic Department, Institute of Orthopaedics, were responsible for the illustrations, and to them I offer my grateful thanks.

\section{REFERENCES}

Bremner, A. E., Neligan, G. A., and Warrick, C. K. (1954) Lancet, 1, 953

Cullen, C. H., and Glass, A. (1955). J. Bone Jt Surg., 37B, 722. Garcia, A., and Grantham, S. A. (1960). Ibid., 42A, 429.

Harris, N. H. (1960). Ibid., 42B, 535.

Platt, H. (1928). Proc. roy.' Soc. Med., 21, 55.

Pritchard, A. E., and Thompson, W. A. L. (1960). J. Bone Jt Surg., 42B, 86 .

Trueta, J., and Morgan, J. D. (1954). Brit. J. Surg., 41, 449.

Winters, J. L., and Cahen, I. (1960). J. Bone Jt Surg., 42A, 691.

\title{
STUDIES ON THE CYTOTOXIC FACTOR IN THYROID DISEASE
}

\section{W. J. IRVINE, B.Sc., M.B., Ch.B., M.R.C.P.Ed.}

Senior Registrar, Department of Therapeutics, University and Royal Infirmary, Edinburgh

\section{[Wrth Special Plate]}

Cells derived from human pathological thyroid glands may be readily cultured in vitro as monolayers (Pulvertaft, Davies, et al., 1959 ; Irvine, 1959, 1960a). In brief, human thyroid tissue obtained at thyroidectomy is cut into fine portions, washed, and transferred to $0.25 \%$ trypsin (Difco) in balanced salt solution. With incubation at $37^{\circ} \mathrm{C}$. and with intermittent shaking, clumps of cells come into suspension, and these can be separated from lymphocytes and red blood cells by very slow centrifugation. Finally the cell clumps are resuspended in nutrient medium containing a total of $20 \%$ human serum and synthetic medium "199" (Morgan et al., 1950) as diluent. The fact that these clumps of trypsinized cells are derived from the thyroid epithelium and not from any other tissue within the thyroid has been established by studying their morphology under the electron microscope (Irvine and Muir, 1962).

Some of the conditions that are necessary for a serum from a patient with Hashimoto's disease to have a cytotoxic effect on human thyroid cells in vitro were reported by Pulvertaft, Doniach, et al. (1959), and many of the properties of the humoral cytotoxic factor responsible for this effect were subsequently described by Irvine (1960b, 1961a) and confirmed by Pulvertaft et al. (1961). The purpose of this paper is to present the results of a more extensive study of the occurrence of the cytotoxic factor and to clarify some points which were hitherto unresolved or controversial. In particular, this paper establishes that the cytotoxic factor is a circulating antibody which, though independent of antibody to thyroglobulin, is closely associated with or identical to circulating complement-fixing antibody directed against thyroid intracellular antigen.

\section{Variation in Susceptibility of Cells Derived from Human Thyroids of Varying Pathology}

While the cytotoxic factor is specific for thyroid cells, not all thyroid cells are equally susceptible to its action (Irvine, 1960b, 1961a). Cells derived from hyperplastic goitres have invariably been susceptible, provided they are tested within the first $24-48$ hours in culture and that complement is present in adequate amounts. On the other hand, cells derived from simple colloid goitres have been poorly or frankly non-susceptible to cytotoxic factor.

It is now possible to express this variation in quantitative terms by testing cells derived from different thyroid glands against cytotoxic sera which had previously been shown to be capable of giving titres as high as $1: 10,000$. Such sera will be referred to hereafter as "standard" cytotoxic sera. Using such a serum the susceptibility of cells from different thyroids was graded by noting the highest dilution of serum at which a cytotoxic effect could still be observed. The results are illustrated in Text Fig. 1, where it is seen that cells derived from thyrotoxic glands often give titres greater than or equal to $1: 10,000$, while cells from " normal" tissue (derived from a histologically normal thyroid gland during parathyroidectomy and

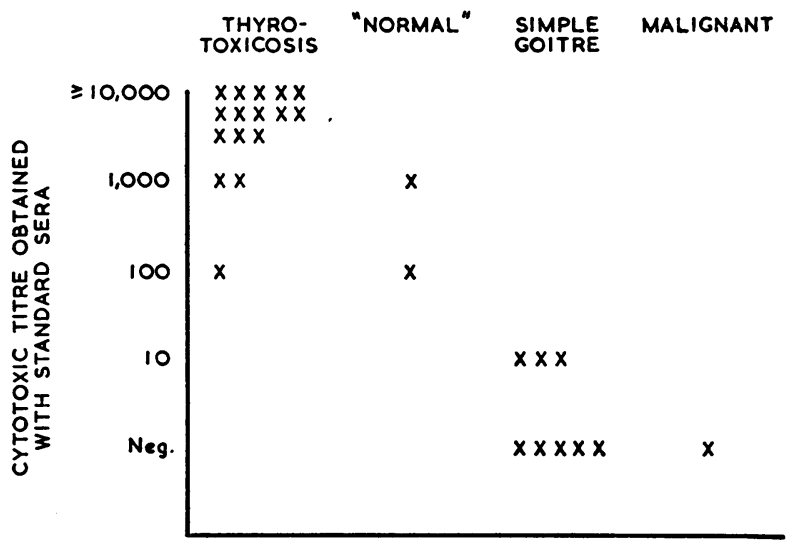

TEXT FIg. 1.-Susceptibility of thyroid cells to cytotoxic factor correlated with pathology of gland of origin. Each cross represents a separate gland.

from thyroid tissue remote from a simple thyroid cyst) gave titres of $1: 100$ and $1: 1,000$ respectively. Cells from non-hyperplastic nodules or colloid goitres gave titres that were either negative or weakly positive $(1: 10)$.

The few thyroid carcinomata I have had the opportunity to study have been difficult to trypsinize, and in only one instance has it been possible to do a satisfactory titration experiment. The histology of this particular gland was that of an adenocarcinoma. Its trypsinized cells were not susceptible to a serum which was known to contain cytotoxic factor in high titre. However, tumours of different histology might well behave differently both in respect to the ease of getting their cells into suspension and in respect to the susceptibility of these cells to cytotoxic factor.

It was noted previously that cells derived from a Hashimoto gland were susceptible to cytotoxic factor, 
and the impression was gained that such cells were intermediate in susceptibility between those of thyrotoxic glands and those of benign nodular or colloid goitres (Irvine, 1960b, 1961a). Unfortunately, it has not been possible to confirm this quantitatively. As with thyroid carcinoma, the trypsinization of Hashimoto glands is often disappointing and may vary appreciably according to the histology.

The use of equal parts of collagenase $(0.1 \%)$ and trypsin $(0.25 \%)$ did not prove helpful in the attempt to obtain cells from one particularly large Hashimoto goitre. Even if such a combination of enzymes had been successful, there would be no certainty that the cells obtained with the help of collagenase would have the same immunological properties as cells obtained by the use of trypsin alone.

It is of interest that the variation in susceptibility of the different types of thyroid tissue shown in Text Fig. 1 more or less parallels the varying amounts of complement-fixing antigen that are known to occur in thyroid cells of differing pathology and presumably of differing functional states (Roitt and Doniach, 1958; Belyavin and Trotter, 1959 ; Trotter and Belyavin, 1961).

In addition to testing the cells from each thyroid gland for susceptibility to "standard" cytotoxic serum, on each occasion the cells were also titrated for susceptibility to any cytotoxic effect which the patient's own serum and which the sera of patients whose thyroid glands had previously been cultured might have on these cells. It was thereby clearly established that any difference between the susceptibilities of different thyroid cells to cytotoxic factor could not be related to whether the experimental system was autologous or isologous.

\section{Cytotoxic Factor as a Gamma-globulin}

It is known that the cytotoxic factor is Seitz-filterable but non-dialysable, and therefore probably protein in nature (Irvine, 1960b, 1961a). However, considerable difficulty was experienced in localizing the factor by paper electrophoresis. Cohn fractionation of a serum containing the factor in high titre revealed cytotoxicity in the fraction "supernatant II and III," while the same fraction derived from a control serum did not have any cytotoxic activity. "Supernatant II and III" in the Cohn fractionation scheme contains a large range of different proteins and includes thyroxine-binding protein. Further studies were clearly required to clarify the protein nature of the cytotoxic factor in more precise terms.

With the collaboration of Dr. D. M. Weir, of the Bacteriology Department, Edinburgh University, it was decided to look again at the gamma-globulin fraction using the de-ethylaminoethyl (D.E.A.E.) column technique (Levy and Sober, 1960). The titre of cytotoxicity in the test serum was determined and the absence of cytotoxicity in the control serum verified before fractionation. The gamma-globulin fraction was eluted into one container and the remainder of the sample into another. The degree of separation of gamma-globulin was checked by cellulose-acetate electrophoresis, and is illustrated for the cytotoxic serum in Text Fig. 2. While the gamma-globulin fraction is virtually $100 \%$ pure, it can be seen that a trace of gamma-globulin has been left with the remainder of the serum.

A sample of each serum and the two fractions derived from a measured volume of each serum were dialysed against synthetic medium " 199 " (Glaxo), corrected for volume, and then titrated for cytotoxicity. This was done for the known positive serum and for the control serum. The results are shown in Table $I$.

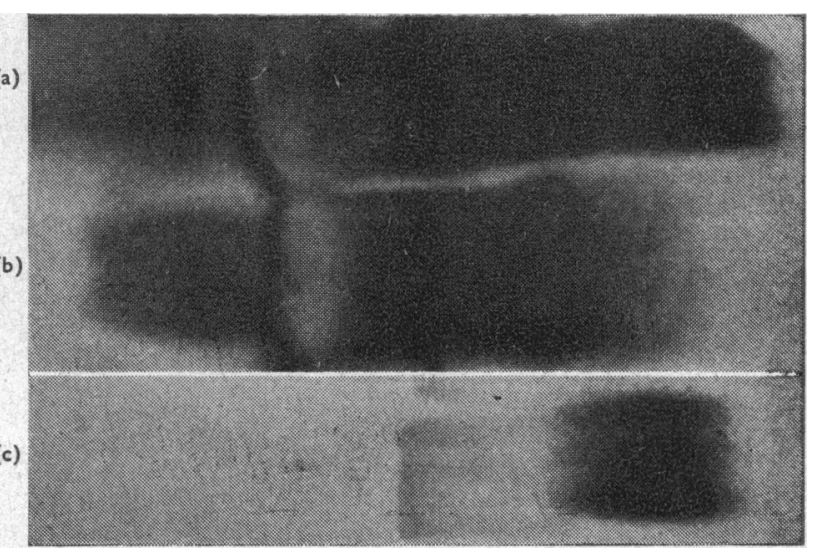

TExT FIG. 2.-Three electrophoretic strips: (a) of cytotoxic serum before fractionation; (b) of same serum after separation of gamma-globulin by D.E.A.E. column; and (c) of gammaglobulin fraction.

I ABLB I.-Results of Tests for Cytotoxicity on the Different Serum Fractions

\begin{tabular}{|c|c|c|c|}
\hline & & \multicolumn{2}{|c|}{ Cytotoxic Titre } \\
\hline & & Cytotoxic Serum & Control Serum \\
\hline $\begin{array}{l}\text { Original serum } \\
\text { Gamma-globulin fraction } \\
\text { Remainder of serum }\end{array}$ & 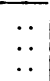 & $\begin{array}{r}\geqslant 10,000 \\
=10,000 \\
10\end{array}$ & $\begin{array}{l}<10 \\
<10 \\
<10\end{array}$ \\
\hline
\end{tabular}

Most of the cytotoxic activity is, in fact, resident in the gamma-globulin fraction, and the low titre in the remainder of the serum could be attributed to the trace of gamma-globulin that is demonstrably left behind. With a different "standard" cytotoxic serum and a different control serum a similar result was obtained. This experiment establishes that the cytotoxic factor is certainly present in the gamma-globulin fraction, but does not exclude the possibility of its existence to a less extent in other fractions as well.

In view of all its known properties, the cytotoxic factor may reasonably be assumed to be a circulating antibody of classic type.

\section{Incidence of Cytotoxic Factor in Serum of Patients with Thyroid Disease and in Controls}

A preliminary survey of the incidence of cytotoxic factor (including the order of titres up to $1: 1,000$ ) throughout the range of thyroid disease was given previously (Irvine, 1960b, 1961a). A larger number of sera have now been tested and the titration extended to include a serum dilution of $1: 10,000$.

In titration experiments stationary tubes were used in place of culture chambers. In the first tube $0.1 \mathrm{ml}$. of test serum was mixed with $0.9 \mathrm{ml}$. of cell suspension; then $0.1 \mathrm{ml}$. of this mixture was added to the next tube containing $0.9 \mathrm{ml}$. of cell suspension, and so on until at the fourth tube a dilution of test serum of $1: 10,000$ was obtained. Of this mixture $0.1 \mathrm{ml}$. was discarded. Then $0.1 \mathrm{ml}$. of fresh normal human serum as a source of complement was added to all tubes containing test sera and $0.2 \mathrm{ml}$. to the control tubes, which contained $0.8 \mathrm{ml}$. of cell suspension. One control tube was set up for each test serum titrated.

Although it was realized that human serum is not the richest, the most constant, or the most convenient source 
of complement, it is possible that the serum of one species might be damaging to the cells of another. The results were regarded as valid only if a cytotoxic effect was demonstrable to a titre of $1: 10,000$ using a "standard" positive serum.

Screening tests controlled by the same criteria were performed invariably in the first instance with the test serum in a final dilution of $1: 10$, and only those sera giving a positive reaction were titrated. Consequently each serum that was titrated was doubly checked for cytotoxicity, using cells of different glands of origin. Cells derived from different glands, but with the same order of susceptibility to cytotoxic factor, gave remarkably consistent results with regard to the screening tests and titrations irrespective of whether the test serum was autologous or homologous.

The incidence of positive screening tests with sera from patients with different types of thyroid disorder and from control patients is shown in Table II. Figure 3 illustrates the distribution of titres found in the sera of these different types of patient.

The general pattern is reminiscent of that which has been established for circulating thyroglobulin antibody

TABLE II.-Incidence of Cytotoxic Antibody in Thyroid Disease

\begin{tabular}{|c|c|c|c|c|c|}
\hline \multirow{2}{*}{\multicolumn{3}{|c|}{ Diagnosis }} & \multirow{2}{*}{$\begin{array}{l}\text { No. } \\
\text { of } \\
\text { Cases }\end{array}$} & \multicolumn{2}{|c|}{ Cytotoxic Titre* } \\
\hline & & & & $\geqslant 10$ & $<10$ \\
\hline \multicolumn{3}{|c|}{ 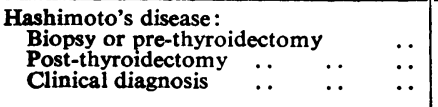 } & $\begin{array}{r}11 \\
8 \\
20\end{array}$ & $\begin{array}{r}10 \\
7 \\
20\end{array}$ & 1 \\
\hline \multicolumn{3}{|c|}{$\begin{array}{l}\text { Hypothyroidism: } \\
\text { Spontaneous (primary) } \\
\text { Hypopituitary (secondary) }\end{array} \begin{array}{l}\text { Post-thyroidectomy or post } \\
\text { 13iI therapy }\end{array}$} & $\frac{15}{6}$ & $\frac{14}{6}$ & $\underline{1}$ \\
\hline \multicolumn{3}{|c|}{ 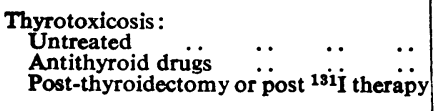 } & $\begin{array}{r}28 \\
24 \\
9\end{array}$ & $\begin{array}{r}17 \\
18 \\
6\end{array}$ & $\begin{array}{r}11 \\
6 \\
3\end{array}$ \\
\hline $\begin{array}{l}\text { Simple goitre: } \\
\text { Pre-thyroidectomy } \\
\text { Clinical diagnosis }\end{array}$ & $\because$ & 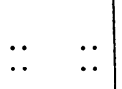 & $\begin{array}{r}20 \\
7\end{array}$ & 3 & $\begin{array}{r}17 \\
7\end{array}$ \\
\hline \multicolumn{3}{|c|}{$\begin{array}{c}\text { Malignant goitre } \\
\text { " } \quad \text { +Hashimoto's disease }\end{array}$} & $\begin{array}{r}10 \\
2\end{array}$ & $\begin{array}{l}3 \\
2\end{array}$ & 7 \\
\hline $\begin{array}{l}\text { Controls: } \\
\text { Hospital } \\
\text { Normal }\end{array}$ & . & $\because$ & $\begin{array}{l}43 \\
17\end{array}$ & $\frac{3}{-}$ & $\begin{array}{l}40 \\
17\end{array}$ \\
\hline
\end{tabular}

Reciprocal of serum dilution.

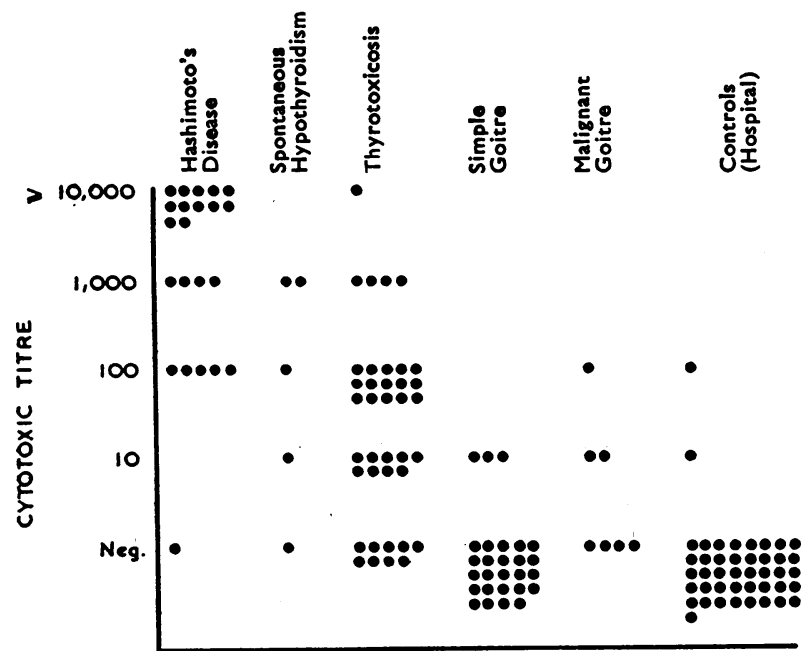

TExT Fig. 3.-Titration of cytotoxic sera. Each dot represents an individual patient. The numbers of positive and negative sera shown here are in the same ratio in the different groups as described in Table II. and for complement-fixing antibody (Roitt and Doniach, 1960 ; Irvine, 1961b)-that is, high titres were found in the Hashimoto and spontaneous hypothyroid groups, moderate titres occurred in the thyrotoxic group, and little cytotoxicity was present in the sera of patients with a simple or malignant goitre or in the control patients. The three hospital patients showing cytotoxic factor were suffering from disseminated lupus erythematosus (cytotoxic titre $=1: 1,000$ ), Addison's disease (cytotoxic titre $=1: 10$ ), and diabetes mellitus (cytotoxic titre $\geqslant 1: 10$ ) respectively.

Correlation between Antibody to Thyroglobulin, Complement-fixing Antibody, and Cytotoxic Factor

Most patients who have developed antibodies against their own thyroid tissue possess both thyroglobulin and complement-fixing antibodies. In determining the relationship of the cytotoxic factor to these antibodies it is necessary to study quantitatively those sera that contain one type of antibody but not the other. The results are illustrated in Table III.

TABLE III.-Correlation Between Thyroglobulin, Complementfixing, and Cytotoxic Antibodies

\begin{tabular}{|c|c|c|c|c|}
\hline Patient & $\begin{array}{c}\text { Agar } \\
\text { Diffusion } \\
\text { Test }\end{array}$ & $\begin{array}{l}\text { Tanned-cell } \\
\text { Haemag- } \\
\text { glutination } \\
\text { Titre }\end{array}$ & $\begin{array}{l}\text { Complement- } \\
\text { fixation Titre } \\
\text { (2.5 M.H.D. of } \\
\text { Complement) }\end{array}$ & $\begin{array}{c}\text { Cytotoxic } \\
\text { Antibodv } \\
\text { (Factor) } \\
\text { Titre }\end{array}$ \\
\hline $\begin{array}{l}\mathbf{A} \\
\mathbf{B} \\
\mathbf{C} \\
\mathbf{D} \\
\mathbf{E} \\
\mathbf{F}\end{array}$ & $\begin{array}{l}\bar{z} \\
\bar{z} \\
\bar{z}\end{array}$ & $\begin{array}{l}\bar{z} \\
\bar{z} \\
=\end{array}$ & $\begin{array}{r}1,024 \\
1,024 \\
512 \\
512 \\
128 \\
32\end{array}$ & $\begin{array}{r}1,000 \\
10,000 \\
\geqslant 1,000 \\
\geqslant 1,000 \\
1,000 \\
1,000\end{array}$ \\
\hline $\begin{array}{l}\mathbf{G} \\
\mathbf{H} \\
\mathbf{I} \\
\mathbf{J}\end{array}$ & $\frac{t}{t}$ & $\begin{array}{r}2,500,000 \\
25,000 \\
25,000 \\
2,500\end{array}$ & $\bar{\Xi}$ & $\begin{array}{r}1,000 \\
100 \\
\geqslant 10 \\
100\end{array}$ \\
\hline $\begin{array}{l}K \\
\mathbf{L} \\
\mathbf{M}\end{array}$ & \pm & $\begin{array}{r}2,500 \\
2,500 \\
250\end{array}$ & $\bar{z}$ & $\overline{\overline{ }}$ \\
\hline
\end{tabular}

The first group of patients in this Table (A-F) indicate that the cytotoxic factor may be present in the absence of trace amounts of thyroglobulin antibody as determined by the very sensitive tanned-cell haemagglutination (T.C.H.) test carried out according to the modification of Fulthorpe et al. (1961). It is notable, however, that all these sera have moderate or high amounts of complement-fixing antibody (using 2.5 M.H.D. of complement and taking $50 \%$ haemolysis as the end-point) specific for thyroid. The third group of patients $(\mathrm{K}-\mathbf{M})$ demonstrate that moderate amounts of thyroglobulin antibody may be present in the absence of cytotoxicity. The middle group of patients $(G-J)$ show moderate or high titres of thyroglobulin antibody but insignificant amounts of complement-fixing antibody, and yet show moderate levels of cytotoxic activity. The interpretation of these findings will be discussed shortly.

Text Figs. 4 and 5 correlate the titres of thyroglobulin and complement-fixing antibody respectively with the titre of cytotoxic factor. The correlation is better for the complement-fixing antibody than it is for antibody to thyroglobulin. From a study of the data in Fulthorpe et al. (1961) it is considered that the lack of correlation between cytotoxic factor and thyroglobulin antibody cannot be explained by the imperfections of the direct haemagglutination technique. The distinction of thyroglobulin antibody from cytotoxic factor is confirmed by the absorption studies previously discussed. No study has been made in the present work of humoral antibody directed against a second colloid antigen (Balfour et al., 


\begin{tabular}{|c|c|c|c|c|}
\hline$\left(\geqslant \begin{array}{c}+++ \\
(\geqslant, 000)\end{array}\right.$ & $x \times$ & $x \times x \times$ & $x \times x$ & $x \times \times x$ \\
\hline $\left.\begin{array}{c}++ \\
(100- \\
1,000\end{array}\right)$ & $\begin{array}{l}x \times x \times x \\
x \times x\end{array}$ & $x \times \times x$ & $\begin{array}{l}x \times x x \\
x \quad x \quad x \quad x \\
x \quad x \quad x\end{array}$ & $x \times$ \\
\hline$\stackrel{+}{(10)})$ & $x \times x$ & $x \times x$ & $x$ & \\
\hline Neg. & & $x \times \times x$ & $\times x$ & $x$ \\
\hline & Neg. & $(5-250)$ & $\left.\begin{array}{c}++ \\
(2,500- \\
25,000\end{array}\right)$ & $\begin{array}{l}++++ \\
(250,000- \\
2,500,000)\end{array}$ \\
\hline
\end{tabular}

Text Fig. 4.-Correlation between titres of cytotoxic and thyroglobulin antibodies. T.C.H. = tanned-cell haemagglutination titre. Each cross represents an individual patient.

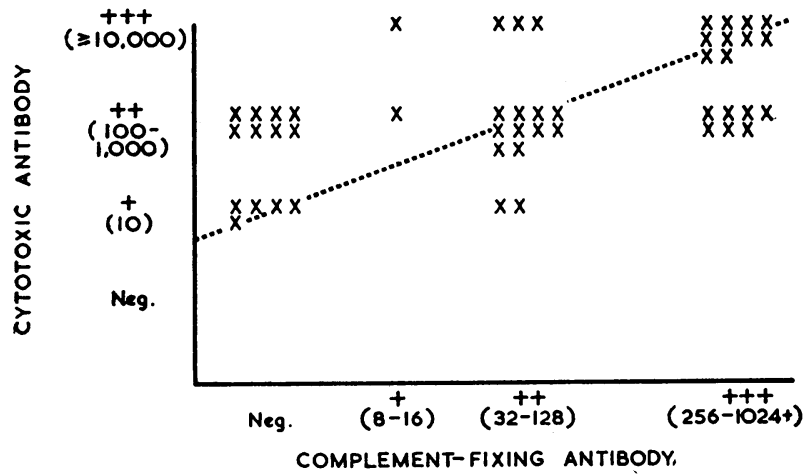

Texr Fig. 5.-Correlation between titres of cytotoxic and complement-fixing antibodies. Each cross represents an individual patient.

1961), but again the absorption studies indicate that this third thyroid antibody is independent of the cytotoxic factor.

Out of the 123 patients screened for cytotoxic factor and for complement-fixing antibody there were 51 patients in whom the cytotoxic factor was absent, and not one of these patients had a positive complementfixation reaction. Of the remaining 72 patients who had significant titres of cytotoxicity, only 49 had a positive complement-fixation reaction. All patients who had a positive complement-fixation reaction specific for thyroid showed cytotoxic activity at a titre of at least $1: 10$.

The most likely interpretation of these observations is that cytotoxic factor and complement-fixing antibody are either closely associated or identical. If this were so, then the explanation for the presence of positive titres of cytotoxic factor in the absence of demonstrable complement-fixing antibody (see Table III and Text Fig. 5) would be simply that the technique of tissue culture is considerably more sensitive than the present method of complement-fixation.

Until such time as evidence arises to the contrary, it can reasonably be assumed that the cytotoxic and complement-fixing antibodies are in fact identical.

\section{Antigenic Properties and Morphology of "Microsomal " Fraction}

"Microsomal" fraction prepared by differential centrifugation after the method of Schneider (1948) is known to contain a high concentration of complementfixing antigen (Belyavin and Trotter, 1959 ; Roitt and
Doniach, 1958). Indeed, this type of antigen is often referred to as microsomal antigen (for example, Fulthorpe et al., 1961). If in fact the cytotoxic and complement-fixing antibodies are closely related or identical, then one would expect the corresponding antigens or antigen to reside in the same cell fraction. That they do coexist is suggested by the observation that a crude extract of a thyrotoxic gland was effective in removing the cytotoxic factor by absorption, while a crude extract of a colloid goitre failed to do so (Irvine, 1960b, 1961a). This experiment has been repeated, and the crude extract of the thyrotoxic gland used for the absorption was shown to contain a large amount of complement-fixing antigen, in contrast to the extract of colloid goitre, which contained comparatively little of this antigen.

In a more precise attempt to establish the identity or otherwise of these two antigens, tissue from a thyrotoxic goitre was divided into three portions. One portion was used to determine the susceptibility of its trypsinized cells in vitro to "standard" cytotoxic serum; the second portion was used to determine the antigenicity of the tissue of origin with regard to complement-fixing antibody; and the third portion was used to prepare " microsomal" fraction. The technique of differential centrifugation adopted was similar to that employed by Belyavin and Trotter (1959) and is illustrated in Text Fig. 6. The end-product was then itself divided into three portions-one to determine the antigenicity of the

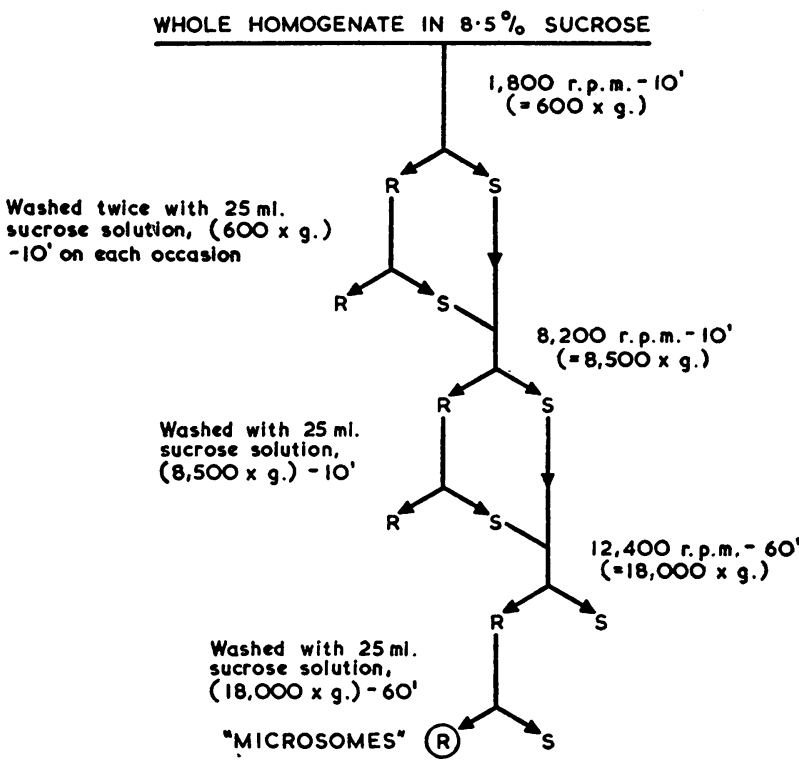

Texr Fig. 6.-Cell fractionation scheme (after Schneider, 1948) by differential centrifugation. $R=$ residue; $S=$ supernatant.

fraction with regard to complement-fixing antibody, a second to assess its effectiveness in removing the cytotoxic factor by absorption, and a third for morphological study under the electron microscope.

The trypsinized cells of this particular thyrotoxic gland (T93) showed a susceptibility in vitro of $1: 10,000$ to a "standard" cytotoxic serum (see Text Fig. 1), and the crude extract of the gland was antigenically potent in a dilution up to $1: 120$ in a complement-fixation test using 2.5 M.H.D. of guinea-pig complement and a serum giving a titre of $1: 1,024$. The "microsomal " fraction was also antigenically potent in a complement-fixation test using the same criteria as just described in a dilution 
up to $1: 480$. Furthermore, there was no doubt that this fraction was effective in absorbing the cytotoxic factor. However, the morphology of the fraction was so heterogeneous that the name "microsomal" is not at present justifiable. As shown in Special Plate, Fig. 1, this fraction consisted of a wide range of particulate matter, including both mitochondria and ribosomes as well as microsomal vesicles. In addition, some of these vesicles contain amorphous material, while others are empty. In view of the specificity of immunological reactions, it would seem best to admit that we do not know the localization of thyroid complement-fixing or cytotoxic antigen beyond saying that it is intracellular. Nevertheless, in so far as it has been possible to study the antigenic content of thyroid tissue at a subcellular level, the experiments described here confirm that the complement-fixing and "cytotoxic" antigens are closely associated one with the other.

\section{In-vitro Studies with Explants of Human Thyroid}

While the cytotoxic effect of complement-fixing humoral antibody on trypsinized cells derived from hyperplastic thyroid tissue is dramatic, the natural history of Hashimoto's disease cannot be said to be equally acute, and Eason (1928) has pointed out that those thyrotoxic patients who eventually become myxoedematous without therapy take many years to do so.

Explants of human normal thyroid glands (obtained at parathyroidectomy), simple goitres, thyrotoxic glands, and lymphadenoid goitres were therefore cultured in plasma clots consisting of $50 \%$ fresh human plasma and $25 \%$ chick-embryo extract and also containing $25 \%$ control or test serum. Unlike the cultures of trypsinized cells, the production of cellular monolayers from the explants was variable even in the presence of the control serum. Consequently, in each experiment eight culture chambers each containing one or two explants were set up against each of the different sera tested: the control serum, the patient's own, and "standard" cytotoxic serum. When the test serum contained thyroglobulin antibody in high titre a dense zone of precipitation formed around the explant. Occasional epithelial-like cells derived from simple goitres of thyrotoxic glands could be seen spreading beyond this area of precipitation. Special Plate, Figs. 2 and 3 illustrate epitheliallike cells spreading in profusion from the explant taken from a simple goitre and cultured in the presence of "standard" cytotoxic serum (cytotoxic titre against trypsinized cells $=1: 10,000$; tanned-cell titre $=$ negative). Likewise, the observations made so far do not suggest that the presence of control or test serum within the plasma clot makes any detectable difference to the behaviour of the other three types of thyroid tissue when cultured in the form of explants. In particular, four experiments with human thyrotoxic tissue failed to show any detectable cytotoxic effect with test serum as compared to the controls.

This failure of the humoral antibody to influence explants of thyroid may be due to the fact that the epithelial-like cells take some two to four days to spread out into the surrounding medium, by which time they may no longer be susceptible to immunological injury. Alternatively, in the absence of trypsin the cytotoxic effect may be much less dramatic and more comparable to the natural history of thyroid disease and correspondingly much less easy to detect.
Special Plate, Figs. 4 and 5 illustrate the striking appearance of the periphery of a Hashimoto explant after two and six days in culture respectively. The round cells are in all probability lymphocytes or plasma cells or a mixture of these cell types, and it is perhaps significant that they do not appear to be taking any particular interest in the fusiform type of cell shown in Special Plate, Fig. 5. Unlike the round cells, the fusiform ones are slower in migrating out of the explant and have the property of adhering to the glass of the culture chamber. The fusiform cells could be derived either from the thyroid epithelium or from fibroblasts.

\section{Discussion and Conclusions}

Much of the current interest in autoimmunity in thyroid disease has been concerned with circulating antibody to thyroglobulin, but there is little convincing evidence to date that this type of antibody is necessarily of aetiological importance. On the other hand, the possible significance of complement-fixing antibody is illustrated by its better correlation with the degree of round-cell infiltration in thyrotoxic tissue removed at partial thyroidectomy, and with the incidence of postoperative hypothyroidism in these patients (Irvine, $1961 \mathrm{~b}$; Irvine, Macgregor, and Stuart, 1962). The identification of thyroid cytotoxic factor with complement-fixing antibody also underlines its relative importance. There is no other naturally occurring autogenous factor known which has been conclusively shown to have a specific and direct adverse effect on the thyroid cell, albeit the trypsinized cell in culture.

Several explanations have been given above for the apparent failure of humoral antibody to influence nontrypsinized thyroid tissue in culture, but the possibility remains that cell-bound rather than humoral antibody is of the greater aetiological significance. The present paper indicates one way in which a pure culture of the round-cell infiltration characteristic of Hashimoto's disease may be obtained, and work is currently in progress in an attempt to determine the immunological properties of these cells in relationship to the patient's serology and with regard to the possibility that they may be of primary importance in the pathogenesis of "autoimmune thyroiditis."

\section{Summary}

A thyroid-specific cytotoxic factor has been previously described to occur in the serum of certain patients with thyroid disease. The presence of this factor is determined by observing the effect of the test serum on trypsinized human thyroid cells in tissue culture. The variation in susceptibility to the cytotoxic factor of trypsinized cells derived from thyroid glands of different pathology has now been expressed in quantitative terms, and it is noted that this parallels the known variation in the content of complement-fixing antigen in these cells and also the functional state of the tissue of origin. In turn this has made it possible to express in a quantitative manner the concentration of cytotoxic factor present in a given serum.

The demonstration that the cytotoxic factor is at least predominantly a gamma-globulin fills an important gap in the argument that the cytotoxic factor is a humoral antibody.

The incidence of the cytotoxic factor in the serum of patients with thyroid disease is similar to that of complement-fixing antibody, but is clearly independent 
of the incidence of antibody to thyroglobulin. Furthermore, in so far as it has been possible to study the antigen content of human thyroid cells at a subcellular level, complement-fixing antigen and the antigen corresponding to the cytotoxic factor have been found to exist in parallel concentrations. Therefore it may reasonably be assumed that the cytotoxic and complement-fixing autoimmune systems are closely associated with each other and, indeed, are probably identical.

The rapidity of the cytotoxic effect in vitro is not in accord with the natural history of Hashimoto's or other forms of thyroid disease in which the factor has been found to occur in a high titre, and it is of interest that cells derived from human thyroid but which have not been subjected to trypsin are apparently uninfluenced by the presence in the nutrient medium of "cytotoxic" antibody.

A method is described whereby the lymphocytic infiltration characteristic of the Hashimoto goitre may be obtained in pure culture, and it is hoped that this may prove helpful in the attempt to clarify the relationship between humoral and cell-bound antibody.

It is a pleasure to acknowledge the support given to me in this work by Professor Sir Derrick Dunlop and Dr. James Robson. Professor John Bruce, Mr. J. R. Cameron, Mr. C. W. A. Falconer, Mr. D. McIntosh, and Professor M. F. A. Woodruff have kindly collaborated in providing thyroid tissue suitable for culture. I am grateful to Dr. L. G. Plaskett, of the Biochemistry Department, Edinburgh University, for doing the cell fractionation, to Dr. M. H. Robertson for collaborating in the tanned-cell haemagglutination tests, to Dr. A. R. Muir for help with the electron micrography, and to Dr. Paul Halberg, Miss Geraldine Walker, and Miss Laura Scarth for their invaluable assistance.

This work was made possible by a generous grant from the Medical Research Council.

\section{REFERENCES}

Balfour, B. M., Doniach, D., Roitt, 1. M., and Couchman, K. G. (1961). Brit. J. exp. Path., 42, 307.

Belyavin, G., and Trotter, W.' R. (1959). Lancet, 1, 648.

Eason, J. (1928). Edinb. med. J., September, p. 169.

Fulthorpe, A. J., Roitt, I. M., Doniach, D., and Couchman, K. (1961). j. clin. Path., 14, 654.

Irvine, W. J. (1959). "The Pathogenesis of Hashimoto's Disease and its Investigation by Thyroid Tissue Culture." Gunning Victoria Jubilee Prize. Edinb. Univ. Libr.

(1960a). J. Endocr., 20, 83.

(1960b). Scot. med. J., 5, 511.

(1961a). In Advances in Thyroid Research, p. 154 Pergamon Press, Oxford.

(1961b). Second Clark Fellowship Lecture. To be published.

published.

- and Muir, A. R. (1962). In press.

Levy, H. B., and Sober, H. A. (1960). Proc. soc. exp. Biol. (N.Y.), 103, 250 .

Morgan, J. F., Morton, H. J., and Parker, R. C. (1950). Proc. Soc. exp."Biol. N.Y., 73, 1 .

Pulvertaft, R. J. V., Davies, J. R., Weiss, L., and Wilkinson, J. H. (1959). J." path. Bact., 77, 19.

Doniach, D., and Roitt, I. M. (1961). Brit. J. exp. Path. 42, 496.

$\mathrm{Roitt}_{\text {I. M., and Doniach, D. (1958). Ib1d., 2, 1027. }}$ and 214.

Roitt, 1. (1960). Brit. med. Bull., 16, 152.

Schneider, W. C. (1948). J. biol. Chem., 176, 259.

Trotter, W. R., and Belyavin, G. (1961). In Advances in Thyroid Research, p. 138. Pergamon Press, Oxford.

The Calouste Gulbenkian Foundation, Lisbon, has made a grant of $£ 20,000$ over three years to enable a committee to be set up to study the recruitment, training, and work of the staff in residential houses for those in need of care, and to publish its report.

\section{DIAGNOSIS OF HODGKIN'S DISEASE BY LIVER BIOPSY}

\author{
BY
}

M. MACLEOD, M.D., F.R.C.P.Ed.

Senior Lecturer in Medicine, University of Aberdeen

AND

A. L. STALKER, M.D.

Senior Lecturer in Pathology, University of Aberdeen

[With Special Plate]

The histological diagnosis of Hodgkin's disease and the related reticuloses is usually made on biopsy of an enlarged superficial lymph-node. Though precise histological classification may be difficult, a clear indication of the nature of the disease process is usually obtained. Unfortunately, however, this is not always possible.

In the early stages superficial lymph-nodes may be unaffected or may show histological changes which are not conclusive (Goldman, 1940 ; Symmers, 1944, 1948 ; Jackson and Parker, 1947; Wintrobe, 1956). Not uncommonly the intrathoracic or intra-abdominal nodes are the first to become enlarged. Extranodal primary foci have been reported in almost every site and structure of the body. General features may be prominent with hepatic enlargement or splenomegaly, but without lymphadenopathy, while pyrexia, fatigue, and anaemia may simulate an infection or a "collagen disease." Haemolytic anaemia due to disordered reticulo-endothelial function may be slight or so severe that it dominates the clinical picture. In such circumstances difficulty in diagnosis is well known.

Series reports on the histological diagnoses revealed by aspiration biopsy of the liver occasionally include an isolated example of Hodgkin's disease or related reticulosis (Sherlock, 1945 ; Volwiler and Jones, 1947 ; Schiff, 1951 ; Tyor and Cayer, 1953). Hepatic enlargement, transient jaundice, biochemical evidence of liver involvement, and structural changes in the portal tracts are, in our experience, more common than textbook descriptions suggest. We have therefore used the aspiration biopsy technique in the investigation of suspected cases of Hodgkin's disease when the diagnosis could not be made by lymph-node biopsy. In each case the modified Gillman technique described by Terry (1949) was used.

\section{Involvement of Liver in Hodgkin's Disease}

Material derived from two sources has been used in this analysis. Twenty-nine cases of Hodgkin's disease were studied post mortem. There was liver involvement in all but three cases. Tissue obtained by aspiration biopsy of the liver was available from 13 patients, in all of whom infiltration was observed in the biopsy specimen. Most of these specimens were obtained early in the disease as estimated from the onset of symptoms. From this material the following picture of the evolving pattern of liver involvement has been obtained.

Site of Infiltrate (Special Plate, Figs. 1 and 2).-The early infiltrate is in the portal space. If it becomes prominent it may encroach into the sinusoids. 


\section{W. J. IRVINE: CYTOTOXIC FACTOR IN THYROID DISEASE}

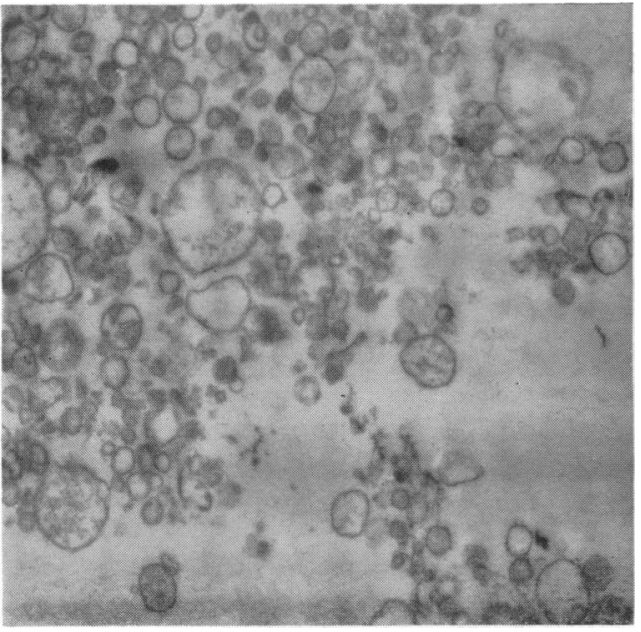

FIG. 1

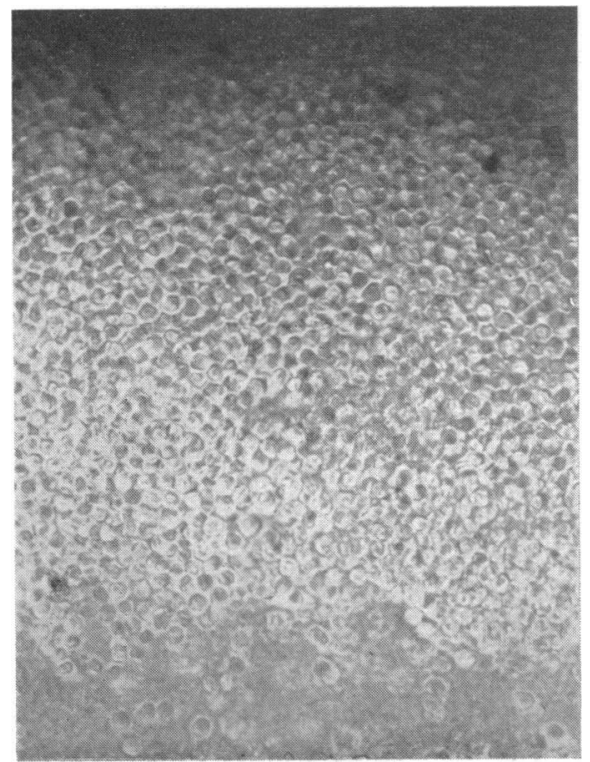

Fig. 4

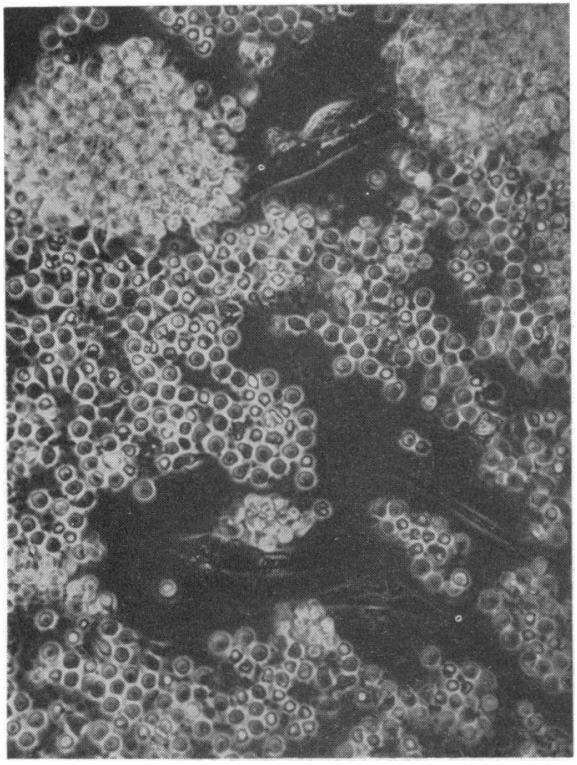

Fig. 5

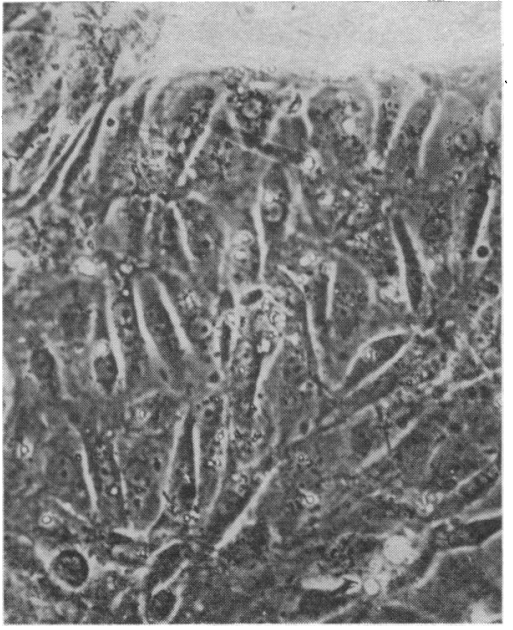

FIG. 2

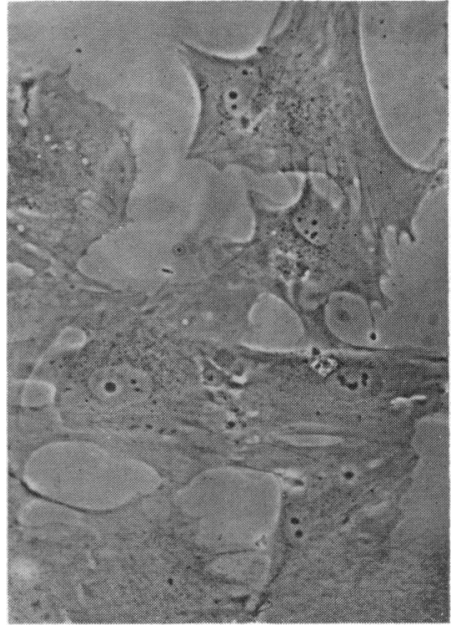

FIG. 3

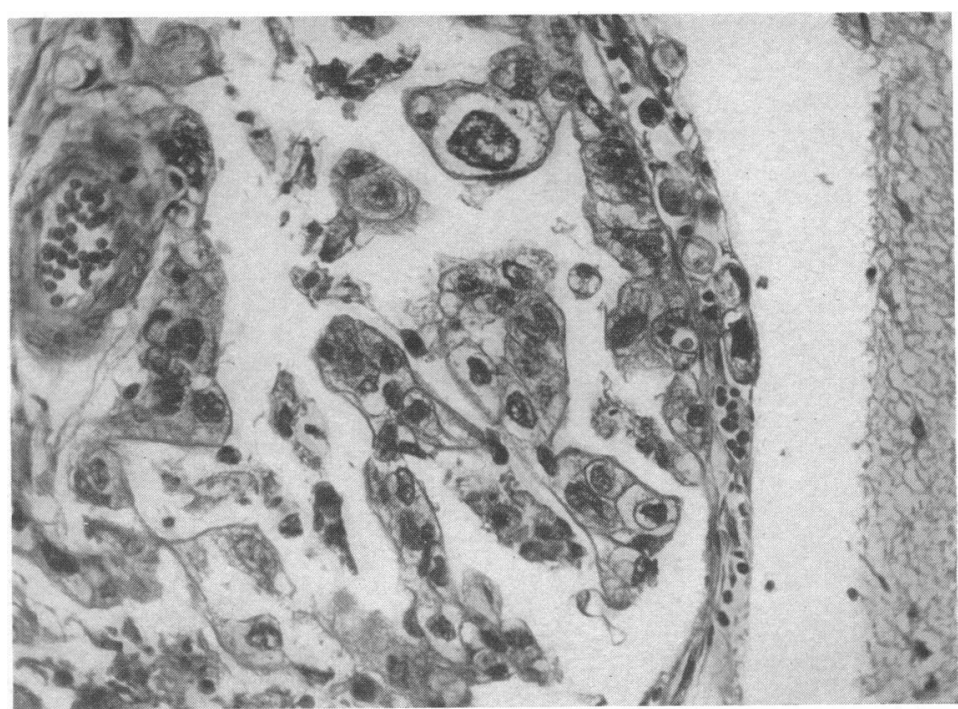

FIG. 2.-Carcinoma cells infiltrating pia-arachnoid. (H. and E. $\times 240$.) 